clear at an informal symposium held at the Ciba Foundation in November, when papers were given on "The Scope of Physical Anthropology and Human Population Biology and their place in Academic Studies". Such a society, named "The Society for the Study of Human Biology", was founded on May 7 at a meeting of forty-four people held in the British Museum (Natural History). Its aims are to advance the study of the biology of human populations and of man as a species in all its aspects-particularly human variability, genetics, ecology, adaptability and evolution-by organizing scientific meetings and by attempting to ensure a continuity of workers for long-term research projects in the field. The Society has accepted as founder members all those who, when approached by the steering committee, had agreed to join. The total membership at present is more than a hundred, and those seeking election should obtain nomination from an existing member. The elected members of the committee for 1958-59 are : Chairman, Dr. A. C. Stevenson; Vice-Chairman, Prof. J. Z. Young; General Secretary, Dr. J. S. Weiner; Programme Secretary, Dr. G. Ainsworth Harrison; Treasurer, Dr. E. Ashton; Committee Members, Dr. N. A. Barnicot, Dr. M. J. R. Healy, Dr. A. E. Mourant, Dr. J. R. Napier, Dr. K. P. Oakley and Dr. J. M. Tanner.

\section{British Agricultural History Society: Annual}

\section{Meeting}

The annual meeting of the British Agricultural History Society was held at the Yorkshire Institute of Agriculture during April 10-12. Two papers on Yorkshire farming were read : one by Mrs. Joan Thirsk on the sixteenth century, and the other by Mr. W. Harwood Long on developments thereafter. Mrs. Thirsk's paper was based on the evidence of probate inventories, a source that is being increasingly used. She pointed out that the sixteenth century was a period of rising prices and growing population. Yorkshire farming had at that time a threefold regional character. The Vale was a district of mixed farming similar to that practised in other parts of the country where open-field arable prevailed. The Dales were stock farms, relying upon valley hay as winter feed. Hay houses then, as now, were scattered over the meadows. The Wolds were a region of wild sheep walks with a little corn growing, mainly barley, on small areas near the villages. Mr. Long, using a number of original documents, led his audience over the more familiar ground of Vale enclosure and Wold reclamation to a description of the modern structure of Yorkshire farming. Dr. P. J. Bowden (Sheffield) read a paper on "Sheep Farming and Wool Production in the Sixteenth and Seventeenth Centuries", a subject about which there has been much controversy, especially in relation to the enclosure of arable for sheep. Dr. Bowden relied largely for the details of sheep husbandry on Henry Best's diary of 1641. Dr. S. R. Eyre (Leeds), speaking on the significance of the upward limit of cultivation on the east moor of North Derbyshire, described the physical configuration of the area, and demonstrated how this had affected farming practice in historical times. It was not possible to plough on the steep western escarpment, but on the easier eastern slopes the plough had been used wherever the gradient was less than $I$ in 4. The plateau was largely covered with recent peat, formed in the past few hundred years, since for lack of a technique for under-surface drainage the region had remained uncultivated.

\section{The Industrial Film in Technical Education}

A CONFERENCE on "The Industrial Film in Technical Education", organized by the Midland Industrial Film Association, was held on May 8 at the G.K.N. Group Research Laboratory at Wolverhampton. The conference, which aimed at clarifying the needs of the technical teacher, was attended by representatives from nine technical colleges in the Midlands area, the University of Birmingham, the Midland Industrial Film Association and invited speakers. It was under the chairmanship of Dr. T. Emmerson, director of research, G.K.N. Group Research Laboratory. Short papers were read by Mr. Marriott, deputy director of training, Stewarts and Lloyds, Dr. N. A. Dudley, head of the Depart. ment of Engineering Production, University of Birmingham, and Dr. H. I. Stonehill, Medway College of Technology, Chatham. A working group consisting of two representatives from technical education and two from the Midland Industrial Film Associa. tion was appointed with the following broad terms of reference : to examine and report on the avail. ability of films suitable for use in technical teaching, with particular reference to the needs of the West Midlands area; and to advise on what steps could best be taken to encourage the provision of more films suitable for the purpose in mind, and to advise on the level of audience at which the need is greatest. This group was asked to report its findings to a more widely representative meeting to be held towards the end of this year.

\section{Wear}

THe new international journal Wear has now been appearing for almost a full year. It is published bimonthly under the skilful trilingual editorship of Dr. G. Salomon, of Delft (subscription price : 1078. 6d. 15 dollars; 57 Dutch florins per volume comprising six issues (approximately 500 pages). Amsterdam : Elsevier Publishing Co., 1957). The honorary editorial and advisory boards have representatives in America, Australia, Britain, Denmark, France, Germany, India, Italy, Japan, Switzerland and the U.S.S.R., and the official languages of the journal are English, French and German; every article has a summary in two languages. Wear is nominally devoted to "fundamentals of friction, lubrication, wear and their control in industry". It is naturally difficult to prevent such a publication becoming narrow and over-specialized and (for a periodical dealing with themes so close to practical affairs) overburdened with technological details. The journal has successfully avoided this tendency, and the articles are of wide interest and of sober scientific value. Two features of particular value are the participation of Russian scientists, and a systematic abstract of current literature at the end of each issue together with details of current international conferences.

\section{Translations of Russian Scientific Literature}

Catalogue No. 2 issued by Consultants Bureau, Inc., is devoted to the physical sciences and lists the reports from Russian journals which are available in English translation as separate articles, in addition to more general information about the translation services carried out by the Bureau, including translations of complete journals, books, proceedings of symposia, and a Russian-English physics dictionary. The Catalogue covers physics, metallurgy, electronics, atomic energy, crystallography and physical chem. 